\title{
Penerapan Pembelajaran Kooperatif NHT Untuk Meningkatkan Aktivitas dan Hasil Belajar Passing Bola Basket
}

\author{
Gede Hendri Setiawan ${ }^{1 *}$ \\ ${ }^{1}$ STKIP Agama Hindu Singaraja, Bali, Indonesia
}

\author{
A R T I C L E I N F O \\ Article history: \\ Received 19 May 2018 \\ Received in revised form \\ 25 July 2018 \\ Accepted 10 October 2018 \\ Available online 29 \\ November 2018 \\ Kata Kunci: \\ NHT, aktivitas, hasil belajar, \\ bola basket. \\ Keywords: \\ NHT, Activities, Learning \\ Outcomes, Basket Ball.
}

\begin{abstract}
A B S T R A K
Penelitian ini bertujuan untuk meningkatkan aktivitas dan hasil belajar bola basket melalui penerapan model pembelajaran kooperatif NHT pada siswa kelas VIII E SMP Negeri 1 Sukasada. Penelitian ini adalah penelitian tindakan kelas yaitu guru sebagai peneliti. Dilaksanakan sebanyak dua siklus yang terdiri dari tahapan perencanaan, tindakan, observasi/evaluasi dan refleksi. Subyek penelitian pada siswa kelas VIII E SMP Negeri 1 Sukasada berjumlah 34 siswa, terdiri dari 20 siswa putra dan 14 siswa putri. Teknik analisis data menggunakan statistik deskriptif.

Berdasarkan hasil data untuk aktivitas belajar bola basket pada observasi awal 5,59 (kurang aktif), dan siklus I menjadi 7,1 (aktif) dan pada siklus 2 meningkat menjadi 8,8 (aktif) . Sedangkan persentase hasil belajar Bola Basket dari observasi awal sebesar 62,2\% (kurang), pada siklus I 72,2\% (Cukup baik) dan 81,7\% (baik) pada siklus II. Berdasarkan analisis data pembahasan disimpulkan bahwa aktivitas dan hasil belajar siswa bola basket meningkat melalui penerapan model pembelajaran kooperatif tipe NHT pada siswa kelas VIII E SMP Negeri
\end{abstract} 1 Sukasada tahun pelajaran 2017/2018. Disarankan kepada guru penjasorkes untuk menggunakan model pembelajaran kooperatif tipe NHT, karena terbukti efektif untuk meningkatkan aktivitas dan hasil belajar.

\section{A B S T R A C T}

This study aims to improve the activity and results of learning the basic techniques of basket ball through the implementation of cooperative learning model NHT on VIII E grade students of SMP Negeri 1 Sukasada. This research is a classroom action research is the teacher as researcher. Conducted in two cycles consisting of stages of planning, action, observation / evaluation and reflection. Subjects were VIII E grade students of SMP Negeri 1 Sukasada, 34 students consisting of 20 male and 14 female student. Data were analyzed by descriptive statistics.

Based on the results of data analysis techniques for learning activities on the basis of passing a basket ball preliminary observations 5,59 (less active), and the first cycle increased to 7,1 (moderately active) and 8,6 (active) in the second cycle. While the percentage of basket ball learned the basic techniques of basket ball preliminary observations by $62,2 \%$ (less), $72,2 \%$ in the first cycle (pretty good) and 81,7 (good) on the second cycle. Based on the results of data analysis and the discussion concluded that the activities and outcomes of student learning the basic techniques of basket ball through the application of cooperative learning model NHT on VIII E grade students of SMP Negeri 1 Sukasada school year 2017/2018. Recommended to Penjasorkes teachers to use cooperative learning model $\mathrm{NHT}$, because it proved to be effective to enhance the activity and learning outcomes. 


\section{Pendahuluan}

Pendidikan memegang peranan yang amat penting untuk menjamin kelangsungan hidup negara dan bangsa, karena pendidikan merupakan wahana untuk meningkatkan dan mengembangkan kualitas sumber daya manusia. "Masyarakat indonesia dengan laju pembangunannya masih menghadapi masalah pendidikan yang berat, terutama berkaitan dengan kualitas, relevansi, dan efesiensi pendidikan" (Mulyasa, 2008:15).

Faktor yang mempengaruhi proses pembelajaran dapat digolongkan menjadi dua, yaitu faktor internal dan faktor eksternal. Faktor internal adalah faktor yang ada dalam diri individu yang sedang belajar seperti jasmani (kesehatan, cacat tubuh), psikologis (inteligensi, perhatian, minat, motivasi, bakat, kematangan, dan kesiapan) dan kelelahan. Sedangkan faktor eksternal adalah faktor yang ada diluar individu seperti keluarga, sekolah dan masyarakat (Slameto, 2003 : 54).

Penjasorkes merupakan bagian integral dari pendidikan secara keseluruhan, bertujuan untuk mengembangkan aspek kebugaran jasmani, ketrampilan gerak, ketrampilan berfikir kritis, ketrampilan sosial, penalaran, stabilitas emosional, tindakan moral, aspek pola hidup sehat dan pengenalan lingkungan bersih melalui aktivitas jasmani olahraga dan kesehatan..

Berdasarkan observasi awal yang dilakukan oleh peneliti pada siswa kelas VIII E SMP N 1 SUKASADA, pada hari jumat tanggal 27 september 2016 pukul 06.00 Wita dalam materi pembelajaran passing bola basket yang berlokasi di lapangan SMP N 1 SUKASADA dengan menggunakan lembar observasi, ditemukan beberapa masalah yang cukup serius baik dari aktivitas maupun hasil belajar siswa yang masih rendah. Hal ini dapat dilihat dari data persentase aktivitas dan hasil belajar yang di peroleh saat observasi awal pada siswa kelas VIII E yang berjumlah 34 orang (14 orang putri dan 20 orang putra), peneliti memperoleh data sebagai berikut. Dilihat dari aktivitas belajar teknik dasar passing bola basket, siswa yang berada dalam kategori sangat aktif tidak ada (0\%), siswa yang berada dalam kategori aktif 4 orang $(6,48), 22$ orang $(74,08 \%)$ siswa berada dalam kategori cukup aktif, 8 orang $(19,44 \%)$ siswa berada dalam kategori kurang aktif dan siswa yang tergolong sangat kurang aktif tidak ada. Rata-rata persentase aktivitas belajar siswa secara klasikal adalah 5.59\%. Dengan persentase yang seperti itu, maka dapat dikatakan aktivitas belajar siswa secara klasikal pada teknik dasar passing bola basket berada dalam kategori cukup aktif. Jika dilihat dari ketuntasan hasil belajar teknik dasar passing bola basket, siswa yang tuntas sebanyak 5 orang $(17,4 \%)$ dan yang tidak tuntas sebanyak 29 orang $(82,6 \%)$, tidak ada siswa yang berada pada kategori sangat baik, 5 orang $(17,4 \%)$ siswa berada pada kategori baik, 17 orang (43,5\%) siswa berada pada kategori cukup baik, 12 orang $(39,1 \%)$ siswa berada pada kategori kurang baik, dan siswa yang tergolong sangat kurang baik tidak ada (0\%). Tingkat ketuntasan belajar siswa secara klasikal adalah $62.2 \%$ dan berada dalam kategori cukup baik, hasil belajar dikatakan berhasil atau tuntas apabila berada pada tingkat ketuntasan 76\% secara individu dan 76\% secara klasikal. Dengan menganalisa data hasil belajar teknik dasar passing bola basket tersebut, hasil belajar masih dalam kategori cukup sehingga belum memenuhi kriteria ketuntasan.

Berdasarkan hasil rekleksi awal, masalah umum yang dialami siswa dalam proses pembelajaran teknik dasar passing bola basket adalah: masih terpusatnya pembelajaran pada guru, siswa masih belajar secara individu, rendahnya aktivitas siswa untuk belajar, dan model pembelajaran masih bersifat konvensional. Adapun permasalahan yang dialami siswa dalam pembelajaran tersebut dari segi aktivitas belajar siswa adalah: (a) dilihat dari segi lisan, siswa belum berani mengemukakan pendapat dalam proses pembelajaran terkait materi teknik dasar passing bola basket, (b) dari segi metrik, siswa belum mampu melakukan serta belum adanya rasa untuk saling membantu dalam mempelajari gerakan-gerakan sesuai dengan materi pelajaran dengan baik dan benar, (c) dari segi mental, siswa belum bisa memecahkan masalah yang dihadapi dalam proses pembelajaran terkait materi teknik dasar passing bola basket, dan (d) dari segi emosional, siswa kurang bersemangat dan kurang bersungguh-sungguh dalam melakukan teknik dasar passing bola basket. Sedangkan untuk hasil belajar permasalahan yang dialami siswa adalah: (a) pada aspek kognitif, masih sangat kurangnya pemahaman siswa mengenai materi teknik dasar passing bola basket, hal ini disebabkan oleh kurangnya kesempatan yang diberikan kepada siswa untuk memahami teori dalam materi teknik dasar passing bola basket, (b) pada aspek afektif, terlihat masih kurangnya suatu jalinan kerjasama dan rasa saling menghargai antara siswa yang satu dengan siswa yang lainnya dalam proses pembelajarannya, dan (c) pada aspek psikomotor permasalahan yang terjadi adalah masih banyak siswa yang masih salah dalam melakukan gerakan, baik dari sikap awal, sikap pelaksanaan, maupun sikap akhir.

Melihat kenyataan tersebut, maka perlu dilakukan inovasi dalam proses pembelajaran Penjasorkes khususnya pada materi pelajaran teknik dasar passing bola basket. Inovasi yang dimaksud yaitu berupa perubahan cara berpikir dari pola pikir yang konvensional menuju pola pikir yang inovatif serta perubahan peran guru yang awalnya sebagai pusat pembelajaran menjadi fasilitator. Melalui peran guru 
sebagai fasilitator dalam pembelajaran, ini dapat mengakibatkan pembelajaran tidak lagi berpusat pada guru melainkan berpusat pada siswa. Salah satu model pembelajaran inovatif yang mampu memfasilitasi siswa dalam menggali pengetahuannya sendiri melalui interaksi secara terbuka adalah model pembelajaran kooperatif.

Model pembelajaran kooperatif dikembangkan menjadi beberapa tipe, salah satunya adalah NHT. Sebagai salah satu alternatif yang tepat untuk dapat meningkatkan aktivitas dan hasil belajar khususnya dalam pembelajaran teknik dasar passing bola basket, dalam kesempatan ini peneliti dan guru sepakat menerapkan model pembelajaran kooperatif tipe NHT dalam pembelajaran teknik dasar passing bola basket. NHT atau penomoran berpikir bersama adalah merupakan jenis pembelajaran kooperatif yang dirancang untuk mempengaruhi pola interaksi siswa dan sebagai alternatif terhadap struktur kelas tradisional (Trianto, 2007: 62). Adapun kelebihan dari model pembelajaran NHT yaitu: setiap siswa menjadi siap semua, dapat melakukan diskusi dengan sungguh-sungguh, serta siswa yang pandai dapat mengajarkan siswa yang kurang pandai.

\section{Metode}

Penelitian ini dilaksanakan pada kelas VIII E SMP Negeri 1 Sukasada tahun pelajaran 2013/2014. Jenis penelitian yang digunakan yaitu penelitian tindakan kelas (PTK). Jumlah subjek penelitian ini yaitu 34 orang siswa. Penelitian ini dilaksanakan sebanyak dua siklus dengan tiap siklus terdiri dari 2 (dua) kali pertemuan pada semester genap. Prosedur penelitian ini terdiri dari empat tahapan yaitu: perencanaan, pelaksanaan tindakan, observasi/evaluasi dan refleksi. Waktu penelitian ini dilaksanakan pada tanggal 5 Februari dan 12 Februari 2014 pada siklus I, sedangkan siklus 2 dilaksanakan pada tanggal 19 dan 26 Februari 2014. Penelitian ini dilaksanakan di lapangan Basket SMP Negeri 1 Sukasada.

Teknik pengumpulan data yang digunakan untuk aktivitas belajar di evaluasi oleh dua orang observer dengan menggunakan lembar observasi aktivitas belajar siswa, sedangkan untuk hasil belajar ada tiga aspek penilaian yaitu aspek kognitif, aspek afektif dan aspek psikomotor. Penilaian kognitif diberikan dengan tes kemampuan yang di buat oleh peneliti, penilaian afektif merupakan pengamatan sikap yang di evaluasi oleh 3 observer dan penilaian psikomotor di evaluasi oleh 3 orang evaluator dengan menggunakan format assesmen hasil belajar siswa Bola Basket. Teknik analisis data yang digunakan dalam penelitian ini adalah teknik analisis statistik deskriptif.

\section{Hasil dan Pembahasan}

Hasil analisis data aktivitas belajar pada siklus I diperoleh aktivitas belajar siswa secara klasikal sebesar 7,1. siswa yang sangat aktif sebanyak 2 orang (6\%), aktif sebanyak 18 orang (53\%) sedangkan siswa yang tidak aktif sebanyak 14 orang (41\%). Adapun rinciannya sebagai berikut: siswa dengan kategori sangat aktif 2 orang (6\%), siswa dengan kategori aktif sebanyak 18 orang dengan persentase $53 \%$, siswa dengan kategori cukup aktif sebanyak 14 orang dengan persentase $41 \%$ dan tidak ada siswa dengan kategori kurang aktif serta kategori sangat kurang aktif.

Tabel 1.1. Data Aktivitas Belajar Siswa Bola Basket pada Siklus I

\begin{tabular}{|c|c|c|c|c|c|}
\hline No & Kriteria & Kategori & Jumlah Siswa & Dalam \% & Ket \\
\hline 1 & $\bar{X} \geq 9$ & Sangat Aktif & 2 siswa & $6 \%$ & \multirow{2}{*}{$\begin{array}{c}20 \text { orang } \\
\text { siswa }(59 \%) \\
\text { Aktif }\end{array}$} \\
\hline 2 & $7 \leq \bar{x}<9$ & Aktif & 18 siswa & $53 \%$ & \\
\hline 3 & $5 \leq \bar{x}<7$ & Cukup Aktif & 14 siswa & $41 \%$ & \multirow{3}{*}{$\begin{array}{c}14 \text { orang } \\
\text { siswa }(41 \%) \\
\text { Tidak Aktif }\end{array}$} \\
\hline 4 & $3 \leq \bar{X}<5$ & Kurang Aktif & 0 siswa & $0 \%$ & \\
\hline 5 & $\bar{X}<3$ & Sangat Kurang Aktif & 0 siswa & $0 \%$ & \\
\hline \multicolumn{3}{|c|}{ Jumlah } & 34 siswa & $100 \%$ & $\begin{array}{c}\text { 34 siswa } \\
(100 \%)\end{array}$ \\
\hline
\end{tabular}


Penelitian hasil belajar siswa Passing (chest pass dan bounce pass) Bola Basket pada siklus I, diperoleh data hasil belajar dimana siswa yang tuntas sebanyak 24 orang siswa dengan persentase 70,6\% dan siswa yang tidak tuntas sebanyak 10 orang siswa dengan persentase 29,4\%. Adapun rincian kategori hasil belajar siswa sebagai berikut: siswa dengan kategori sangat baik sebanyak 0 orang dengan persentase $0 \%$, siswa dengan kategori baik sebanyak 24 orang dengan persentase 70,6\%, siswa dengan kategori cukup baik sebanyak 10 orang dengan persentase 29,4\% dan tidak ada siswa dengan kategori kurang baik maupun kategori sangat kurang baik, dengan persentase secara klasikalnya 70,5\% dengan kategori cukup baik (tidak tuntas).

Tabel 1.2. Data Hasil Belajar Siswa Bola Basket pada Siklus I

\begin{tabular}{|c|c|c|c|c|c|c|}
\hline No & $\begin{array}{c}\text { Rentang } \\
\text { Skor }\end{array}$ & $\begin{array}{c}\text { Banyak } \\
\text { Siswa }\end{array}$ & Persentase & $\begin{array}{l}\text { Nilai } \\
\text { Huruf }\end{array}$ & Kategori & Ket \\
\hline 1 & $85-100$ & 0 siswa & $0 \%$ & A & Sangat Baik & $\begin{array}{c}24 \text { orang } \\
\text { siswa }(70,6 \%)\end{array}$ \\
\hline 2 & $76-84$ & 24 siswa & $70,6 \%$ & B & Baik & Tuntas \\
\hline 3 & $60-75$ & 10 siswa & $29,4 \%$ & $\mathrm{C}$ & \multirow{3}{*}{$\begin{array}{c}\text { Cukup Baik } \\
\text { Kurang baik } \\
\text { Sangat } \\
\text { Kurang }\end{array}$} & \multirow{3}{*}{$\begin{array}{c}10 \text { orang } \\
\text { siswa }(29,4 \%) \\
\text { Tidak Tuntas }\end{array}$} \\
\hline 4 & $50-59$ & 0 & $0 \%$ & $\mathrm{D}$ & & \\
\hline 5 & $0-49$ & 0 & $0 \%$ & $\mathrm{E}$ & & \\
\hline & lah & 34 & $100 \%$ & & & $\begin{array}{c}34 \text { siswa } \\
(100 \%)\end{array}$ \\
\hline
\end{tabular}

Hasil analisis data aktivitas belajar siswa pada siklus II diperoleh aktivitas belajar siswa secara klasikal sebesar 8,8 dengan tingkat keaktifan sudah aktif. Siswa yang aktif sebanyak 34 orang siswa dengan persentase $100 \%$ dan tidak ada siswa yang tidak aktif. Adapun rincian kategori aktivitas belajar siswa adalah sebagai berikut: siswa dengan kategori sangat aktif sebanyak 9 orang dengan persentase $27 \%$, siswa dengan kategori aktif sebanyak 25 orang dengan persentase $73 \%$ dan tidak ada siswa dengan kategori cukup aktif, kurang aktif maupun sangat kurang aktif.

Tabel 1.3. Data Aktivitas Belajar Siswa Bola Basket pada Siklus II

\begin{tabular}{cccccc}
\hline No & Kriteria & Kategori & Jumlah Siswa & Dalam \% & Ket \\
\hline 1 & $\bar{X} \geq 9$ & Sangat Aktif & 9 siswa & $27 \%$ & $\begin{array}{c}34 \text { orang siswa } \\
(100 \%) \\
\text { Aktif }\end{array}$ \\
2 & $7 \leq \bar{X}<9$ & Aktif & 25 siswa & $73 \%$ & 0 siswa \\
3 & $5 \leq \bar{X}<7$ & Cukup Aktif & $0 \%$ & 0 orang siswa \\
$(0 \%)$ \\
4
\end{tabular}

Penelitian hasil belajar pada siklus II dengan materi Passing (chest pass dan bounce pass) bola basket diperoleh data hasil belajar dimana siswa yang tuntas sebanyak 34 orang dengan persentase $100 \%$ dan siswa yang tidak tuntas sebanyak 0 orang dengan persentase $0 \%$. Adapun rincian kategori sebagai berikut: siswa dengan kategori sangat baik sebanyak 24 orang dengan persentase 70,6\%, siswa dengan kategori baik sebanyak 10 orang dengan perserntase 29,4\%, siswa dengan kategori cukup baik sebanyak 0 orang dengan persentase $0 \%$ dan tidak ada siswa dengan kategori kurang baik maupun sangat kurang baik. Persentase ketuntasan hasil belajar siswa passing (chest pass dan bounce pass) bola basket secara klasikal pada siklus II adalah 81,7\% berada pada rentang 76-84 dengan kategori baik dan sudah memperoleh nilai rata-rata hasil belajar sebesar $75 \%$. 
Tabel 1.4. Data Hasil Belajar Bola Basket pada Siklus II

\begin{tabular}{|c|c|c|c|c|c|c|}
\hline No & $\begin{array}{l}\text { Rentang } \\
\text { Skor }\end{array}$ & $\begin{array}{c}\text { Banyak } \\
\text { Siswa }\end{array}$ & Persentase & $\begin{array}{l}\text { Nilai } \\
\text { Huruf }\end{array}$ & Kategori & Ket \\
\hline 1 & $85-100$ & 24 siswa & $70,6 \%$ & A & Sangat Baik & \multirow{2}{*}{$\begin{array}{c}34 \text { orang } \\
\text { siswa }(100 \%) \\
\text { Tuntas }\end{array}$} \\
\hline 2 & $76-84$ & 10 siswa & $29,4 \%$ & B & Baik & \\
\hline 3 & $60-74$ & & $0 \%$ & $\mathrm{C}$ & Cukup Baik & \multirow{3}{*}{$\begin{array}{c}0 \text { orang siswa } \\
\text { (0\%) Tidak } \\
\text { Tuntas }\end{array}$} \\
\hline 4 & $50-59$ & 0 & $0 \%$ & $\mathrm{D}$ & Kurang baik & \\
\hline 5 & $0-49$ & 0 & $0 \%$ & $\mathrm{E}$ & Sangat Kurang & \\
\hline \multicolumn{2}{|c|}{ Jumlah } & 34 & $100 \%$ & & & $\begin{array}{c}34 \text { orang } \\
\text { siswa }(100 \%)\end{array}$ \\
\hline
\end{tabular}

Pada observasi awal yang dilakukan pada siswa kelas VIII E SMP Negeri 1 Sukasada diketahui bahwa aktivitas belajar kurang aktif secara klasikal dan hasil belajar tidak tuntas secara klasikal. Hal ini dikarenakan saat proses pembelajaran berlangsung banyak siswa tidak bersemangat dalam melakukan gerakan dan banyak siswa tidak memperhatikan guru saat menjelaskan materi sehingga aktivitas dan hasil belajar siswa tidak maksimal. Untuk itu peneliti mencoba menerapkan model pembelajaran yang inovatif yaitu model pembelajaran kooperatif tipe $N H T$. NHT merupakan suatu model pembelajaran yang lebih mengedepankan kepada aktivitas siswa dalam mencari, mengolah, dan melaporkan informasi dari berbagai sumber yang akhirnya dipresentasikan di depan kelas. Dengan menerapkan model pembelajaran koopertif tipe $N H T$ aktivitas dan hasil belajar siswa menjadi lebih baik dari observasi awal. Pada siklus I aktivitas belajar masih tidak aktif dikarenakan masih ada 14 siswa yang tidak aktif namun dengan diberikan tindakan pada siklus II aktivitas belajar meningkat sehingga 34 siswa menjadi aktif.

Berdasarkan uraian tersebut, ini berarti bahwa tingkat penguasaan materi Passing (chest pass dan bounce pass) pada siklus II sudah memenuhi KKM yang ditetapkan pada mata pelajaran penjasorkes di kelas VIII E SMP Negeri 1 Sukasada, yakni sebesar 76 dari nilai maksimal 100. Secara klasikal penelitian ini dianggap berhasil karena telah mencapai target yakni 76\% siswa di kelas terteliti telah memperoleh rata-rata nilai sebesar 76 berdasarkan KKM dari SMP Negeri 1 Sukasada tersebut. Karena sudah tercapainya target yang ditentukan maka penelitian ini dihentikan sesuai dengan rancangan penelitian yang telah direncanakan sebelumnya. Keberhasilan dalam penelitian sesuai dengan teori-teori yang mendukung dalam proses pembelajaran. Hamalik (2008: 171-172) menyatakan bahwa pembelajaran yang efektif adalah pembelajaran yang menyediakan kesempatan belajar sendiri dan beraktivitas sendiri kepada siswa. Siswa belajar dan beraktivitas sendiri untuk memperoleh pengalaman, pengetahuan, pemahaman, dan tingkah laku lainnya serta mengembangkan keterampilan yang bermakna.

Jadi dapat disimpulkan bahwa kegiatan atau aktivitas belajar siswa merupakan dasar untuk mencapai hasil belajar yang optimal. Selain itu hasil penelitian ini juga dikuatkan dari peneliti-peneliti sebelumnya diantaranya: I Made Edy Sugiartha tahun 2011 yang berjudul penerapan model pembelajaran kooperatif tipe NHT untuk aktivitas dan hasil belajar passing control sepak bola pada siswa kelas VII A SMP Negeri 1 Kubu tahun pelajaran 2011/2012. Dewa Nyoman Sulaksana tahun 2011 yang berjudul implementasi model pembelajaran kooperatif tipe $N H T$ untuk meningkatkan aktivitas dan hasil belajar teknik dasar shoting bola basket pada siswa kelas X-2 SMA Negeri 3 Singaraja tahun pelajaran 2011/2012.

\section{Simpulan Dan Saran}

Berdasarkan hasil penelitian dan analisis data, maka dapat disimpulkan sebagai berikut. Aktivitas belajar Passing (chest pass dan bounce pass) bola basket meningkat melalui penerapan model pembelajaran kooperatif tipe NHT pada siswa kelas VIII E SMP Negeri 1 Sukasada Tahun Pelajaran $2017 / 2018$.

Berdasarkan hasil penelitian, maka dapat disarankan beberapa hal antara laian sebagai berikut: Guru SMPN 1 Sukasada, hendaknya terus berusaha untuk meningkatkan kemampuannya dalam mengembangkan materi, menyampaikan materi, serta dalam mengelola kelas, sehingga kualitas pembelajaran yang dilakukannya dapat terus meningkat seiring dengan peningkatan kemampuan yang dimilikinya. Selain itu, guru hendaknya mau membuka diri untuk menerima berbagai bentuk masukan, saran, dan kritikan agar dapat lebih memperbaiki kualitas mengajarnya. Serta guru harus lebih kreatif dan 
inovatif dalam menerapkan metode yans sesuai dengan tingkat kemauan siswa supaya pembelajaran lebih bervariasi dan tidak monoton menggunakan paradigma lama sehingga siswa tidak bosan. Bagi siswa, agar supaya selalu fokus dalam mengikuti pelajaran supaya hasilnya lebih optimal. Bagi sekolah, hendaknya berusaha menyediakan fasilitas yang dapat mendukung kelancaran kegiatan belajar mengajar di SMPN 1 Sukasada. Guru dapat menjadikan hasil Penelitian Tindakan Kelas ini sebagai reference untuk melakukan kegiatan serupa.

\section{Daftar Rujukan}

Agung, A. A. Gede. 2011. Metodelogi Penelitian Pendidikan. Singaraja: Fakultas Ilmu Pendidikan Universitas Pendidikan Ganesha.

Agung, A. A. Gede. 2014. Metodologi Penelitian Pendidikan. Singaraja: Undiksha.

Depdiknas, 2006. Kurikulum 2006 Standar Kompetensi Mata Pelajaran Pedidikan Jasmani. Jakarta : Departemen Pendidikan Nasional.

Eka, Juniarsih I Putu. 2013. Penerapan NHT Untuk Meningkatkan Aktivitas Dan Hasil Belajar Passing Bola Basket. Singaraja: Universitas Pendidikan Ganesha.

Sanjaya, Wina. 2009. Strategi Pembelajaran Berorientasi Standar proses pendidikan. Jakarta: Kencana.

Slameto. 2003. Belajar dan Faktor Faktor yang Mempengaruhinya. Jakarta: PT Rineka Cipta.

Sugiartha Edy, I Made. 2011. Penerapan Model Pembelajaran Kooperatif Tipe Numbered Head Together (NHT) untuk Meningkatkan Aktivitas dan Hasil Belajar Passing Control Sepak Bola pada siswa kelas VII A SMP Negeri 1 Kubu. Singaraja: Universitas pendidikan Ganesha.

Sulaksana Nyoman, Dewa. 2011. Implementasi Model Pembelajaran Kooperatif Tipe Numbered Head Together (NHT) untuk Meningkatkan Aktivitas dan Hasil Belajar Teknik Dasar Shoting pada siswa kelas X 2 SMA Negeri 3 Singaraja. Singaraja: Universitas Pendidikan Ganesha. 